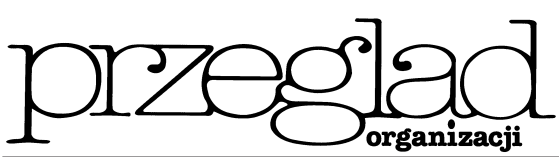

\title{
Wdrożenie i stosowanie controllingu a kształt struktury organizacyjnej przedsiębiorstwa
}

https://doi.org/10.33141/po.2005.09.08

Przegląd Organizacji, Nr 9 (788), 2005, ss. 35-39 www.przegladorganizacji.pl

\section{Wprowadzenie}

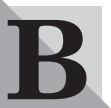

urzliwy charakter otoczenia przedsiębiorstw stanowi przesłankę do wdrażania i stosowania współczesnych koncepcji i metod zarządzania. Celem stosowania tych rozwiązań jest usprawnianie bądź wspomaganie realizacji procesu zarządzania. Istotne zatem wydaje się rozpoznanie relacji pomiędzy współczesnymi koncepcjami i metodami zarządzania a jego podstawowymi funkcjami, tj. planowaniem, organizowaniem, motywowaniem i kontrolą.

Jedną z najbardziej rozwiniętych, zarówno w teorii, jak i w praktyce gospodarczej, współczesnych koncepcji zarządzania jest controlling. Mimo wieloznacznego pojmowania controllingu, jego wpływ na kształt poszczególnych elementów systemu zarządzania przedsiębiorstwem jest uznawany powszechnie i jak podkreśla wielu autorów istnieje konieczność rozpoznania tych związków ${ }^{1}$. Powiązania controllingu z funkcjami planowania i kontroli wielokrotnie były przedmiotem rozważań teoretycznych i badań empirycznych, których wyniki potwierdzają wpływ controllingu na realizację planowania i kontroli w przedsiębiorstwie. Problem oddziaływania controllingu na realizację funkcji motywowania podejmowany jest rzadziej i najczęściej w odniesieniu do wybranej grupy pracowników, a mianowicie kierownictwa utworzonych centrów odpowiedzialności. Istotne wydaje się więc również rozpoznanie związków pomiędzy stosowaniem controllingu a funkcją organizowania i powstałą w jej wyniku strukturą organizacyjną przedsiębiorstwa. Rodzą się zatem pytania: Czy wdrożenie i stosowanie controllingu powoduje zmiany w strukturze organizacyjnej przedsiębiorstwa? Jeśli tak, to jaki jest charakter i kierunek tych zmian, jak zmienia się natężenie cech (wymiarów) struktury organizacyjnej pod wpływem controllingu?

Struktura organizacyjna pojmowana jest przez autora, zgodnie z definicją zaproponowaną przez L. Krzyżanowskiego, jako zbiór stosunków organizacyjnych określony na zbiorze komórek organizacyjnych sfery realnej i aparacie zarządzającym organizacją ${ }^{2)}$. Jest ona postrzegana przez autora przez pryzmat czterech cech, a mianowicie: konfiguracji, specjalizacji, centralizacji i formalizacji. Controlling natomiast traktowany jest jako system wspomagający zarządzanie przedsiębiorstwem (podsystem pełniący funkcje o charakterze doradczym).
Celem niniejszego opracowania jest prezentacja fragmentów wyników badań empirycznych, poświęconych identyfikacji zmian struktury organizacyjnej przedsiębiorstwa związanych z wdrożeniem i stosowaniem controllingu w przedsiębiorstwie. Prezentowane badania wpisują się w nurt badań sytuacyjnych nad czynnikami strukturotwórczymi, w których obecnie zauważalna jest pewna luka. Mimo szerokiego zakresu i kompleksowości badań nad determinantami strukturalnymi, prowadzonych w połowie ubiegłego wieku, nie uwzględniały one takich elementów, jak współczesne koncepcje i metody zarządzania. W okresie, w którym badania te były prowadzone, nowoczesne rozwiązania jeszcze nie istniały lub były w stadium wczesnego rozwoju, nie były zatem traktowane w kategoriach potencjalnych czynników mogacych oddziaływać na kształt struktury organizacyjnej. Obecnie ich wpływ wydaje się być zauważalny, co rodzi potrzebę wypełnienia powstałej luki badawczej.

Podstawą prezentowanych rozważań jest krajowa i zagraniczna literatura przedmiotu oraz wyniki badań empirycznych przeprowadzonych w 2004 roku w 56 dolnośląskich przedsiębiorstwach. Badania finansowane były ze środków Komitetu Badań Naukowych w roku 2004 jako projekt badawczy.

\section{Controlling a struktura organizacyjna przedsiębiorstwa}

$\mathbf{K}$

oncepcja controllingu zawiera w swoich założeniach wiele postulatów i wytycznych odnośnie do pożądanego kształtu struktury organizacyjnej przedsiębiorstwa. Dotyczą one między innymi takich obszarów, jak wyodrębnienie centrów odpowiedzialności i powołanie komórek ds. controllingu. W związku z dokonywaniem zmian w tych obszarach konieczne jest rozwiązanie kilku, istotnych jak się wydaje kwestii, warunkujących sprawność implikowanych rozwiązań. Problemy te można ująć w formie następujących pytań:

- ile centrów odpowiedzialności wyodrębnić i jak duże mają to być jednostki,

- na którym szczeblu zarządzania,

- czy utworzyć je na bazie istniejących komórek organizacyjnych, a jeśli nie, to jakie kryterium wyodrębniania zastosować,

- jaki ma być stopień odpowiedzialności wyodrębnionych komórek, 
- w jaki sposób dokonywać wyodrębniania centrów odpowiedzialności: jednorazowo czy stopniowo,

- jaką formę powinna mieć komórka controllingowa, czy ma to być pojedyncze stanowisko, sekcja czy dział,

- czy ma to być nowo utworzona komórka czy powstała w wyniku przekształcenia komórki dotychczas istniejącej,

- gdzie umiejscowić komórkę ds. controllingu w hierarchii organizacyjnej, komu powinna ona bezpośrednio podlegać,

- jaki powinien być jej zakres zadań, uprawnień i odpowiedzialności, a także relacje z innymi komórkami organizacyjnymi przedsiębiorstwa?

Podstawy teoretyczne koncepcji controllingu zawierają wiele różnorodnych, niekiedy przeciwstawnych, a niekiedy nie dających się ze sobą porównywać wskazówek odnośnie do wskazanych problemów. Ograniczone ramy objętościowe niniejszego opracowania nie pozwalają na ich prezentację, stąd autor zmuszony jest odesłać czytelnika do literatury przedmiotu. Nie sa to z reguły jednak uniwersalne zasady i wzorce, a przynajmniej nie należy ich w ten sposób traktować. Przedstawiane przez poszczególnych autorów wskazówki i zalecenia znacznie się bowiem od siebie różnią, a przy próbie ich aplikacji do praktyki zarządzania konieczne jest uwzględnienie celów, wielkości i specyfiki organizacji oraz otoczenia, w którym funkcjonuje.

\section{Controlling a struktura organizacyjna w świetle wyników badań empirycznych}

W celu identyfikacji związków pomiędzy wdrożeniem i stosowaniem controllingu a kształtem struktury organizacyjnej w praktyce gospodarczej, przeprowadzono badania empiryczne składające się $\mathrm{z}$ dwóch zasadniczych faz. W pierwszej fazie badań wykorzystano metodę ankietową. Po przygotowaniu kwestionariusza ankietowego i przetestowaniu go w ramach badań pilotażowych w 6 przedsiębiorstwach, został on rozesłany pocztą tradycyjna i elektroniczną do 870 dolnośląskich przedsiębiorstw. Łącznie uzyskano 56 odpowiedzi zwrotnych. W drugiej fazie badań, tzw. badaniach właściwych, wykorzystano metodę studium przypadku, poddając wnikliwej analizie 9 przedsiębiorstw, spośród firm biorących udział w badaniach wstępnych. Do zbierania informacji, obok kwestionariusza ankietowego, wykorzystano w tym wypadku obserwację, analizę dokumentacji oraz wywiady z kierownictwem.

Wyniki przeprowadzonych badań wstępnych wskazują, że wdrożenie i stosowanie controllingu implikowało zmiany w strukturze organizacyjnej polegające między innymi na wyodrębnianiu centrów odpowiedzialności i tworzeniu komórek controllingowych. Wyodrębnienie centrów odpowiedzialności zadeklarowało $91 \%$ przedsiębiorstw stosujących koncepcję controllingu. Tworzone jednostki najczęściej miały status centrów kosztowych. Centra zysku (wynikowe) wyodrębniono w niespełna połowie, a centra inwestycyjne jedynie w co dziesiątym przedsiębiorstwie. Częstym zjawiskiem była wielostopniowa organizacja ośrodków odpowiedzialności, tj. współwystępowanie np. centrów kosztów i centrów zysku. W dwóch trzecich przypadków wyodrębnianie centrów miało charakter stopniowy, co oznacza, że ośrodki odpowiedzialności tworzone były etapami, początkowo np. obejmując działalność podstawową, a następnie całe przedsiębiorstwo. W większości przypadków centra odpowiedzialności były tworzone poprzez osadzanie na dotychczas istniejacych jednostkach organizacyjnych. Najczęstszymi kryteriami wyodrębniania centrów odpowiedzialności były kryteria produktowe (57\%), funkcjonalne (50\%), regionalne (27\%). Również w tym przypadku stwierdzono współwystępowanie większej liczby kryteriów w poszczególnych przypadkach, tj. równoległe stosowanie różnych kryteriów do poszczególnych jednostek, np. kryterium produktowego $\mathrm{w}$ sferze działalności podstawowej i funkcjonalnego w sferze działalności pomocniczej.

W większości badanych firm utworzono komórki ds. controllingu (91\%). Rodzaj i wielkość komórki ds. controllingu w dużym stopniu związany był $\mathrm{z}$ wielkością firmy. W dużych firmach przeważały działy controllingu, zaś w średnich i małych firmach sekcje i pojedyncze stanowiska ${ }^{3)}$. Komórka ds. controllingu częściej powstawała wskutek przekształcenia istniejacej dotychczas komórki (57\%), niż była tworzona jako nowa (43\%). Różne było jej umiejscowienie w strukturze organizacyjnej: najczęściej podlegała bezpośrednio dyrektorowi ds. ekonomicznych, ekonomiczno-finansowych, finansowych czy finansowo-księgowych (57\%), rzadziej zajmowała tzw. pozycję nadrzędna (23\%), podlegając bezpośrednio prezesowi zarządu/ dyrektorowi naczelnemu. Zakres zadań komórki ds. controllingu był bardzo zróżnicowany, od nadzoru nad przebiegiem prac planistyczno-kontrolnych i analitycznych do bezpośredniego i samodzielnego ich wykonywania włącznie. Ogólnie, uzyskane na podstawie badań wstępnych wyniki wskazują na istnienie związków pomiędzy stosowaniem koncepcji controlingu a kształtem struktury organizacyjnej przedsiębiorstwa i tym samym zdają się potwierdzać istotność podejmowanego problemu badawczego.

Wyodrębnianie centrów odpowiedzialności i tworzenie komórek ds. controllingu powodowało zmiany natężenia wytypowanych cech strukturalnych, a mianowicie konfiguracji, specjalizacji, centralizacji i formalizacji. Największe zmiany stwierdzono w wymiarze centralizacji. W wyniku przekazywania uprawnień decyzyjnych kierownikom utworzonych centrów odpowiedzialności, stopień centralizacji ulegał zmniejszeniu. Częstym zjawiskiem było ustalanie w budżetach określonych limitów, w ramach których kierownictwo jednostki samodzielnie decyduje o zakupie niskocennych środków trwałych, materiałów, przeprowadzaniu niezbędnych remontów itd. Efektem decentralizacji jest wzrost elastyczności w działaniu i lepsze dostosowywanie się do określonych warunków. Decydenci znajdują się bowiem bliżej rzeczywistych problemów i z reguły mają lepsze możliwości ich trafnego rozpoznania. Częstym zjawiskiem było również delegowanie uprawnień związanych z realizacją polityki personalnej w ramach jednostki. Towarzysząca wdrożeniu controllingu decentralizacja zarządzania możliwa jest dzięki temu, że wprowadzenie zadań i narzędzi controllingowych w znacznym stopniu roz- 
wija świadomość ekonomiczną kadry kierowniczej i pracowników zatrudnionych w obszarach produkcyjnych.

Nieco mniejsze, ale zbieżne kierunkowo zmiany zidentyfikowano w natężeniu kolejnych wyróżnionych wymiarów strukturalnych, tj. specjalizacji i konfiguracji. Zmiany te dotyczyły przede wszystkim poszerzenia zakresu zadań na stanowiskach kierowników jednostek o budżetowanie i analizę odchyleń, analizę poszczególnych pozycji kosztów itp. Zakres zadań rozszerzał się również w wyniku zwiększenia uprawnień kierowników, np. o sprawy personalne w obrębie jednostki, prowadzenie gospodarki materiałowej i narzędziowej czy remonty. Zwiększenie zakresu zadań tych komórek powodowało zmniejszenie stopnia specjalizacji funkcjonalnej, gdyż dotychczas funkcje te sprawowały specjalnie wyodrębnione do tego celu komórki.

W układzie komórek organizacyjnych (konfiguracji) zmiany nie były znaczące, gdyż jak już sygnalizowano w większości przypadków zarówno centra odpowiedzialności, jak i komórki ds. controllingu tworzone były „przez osadzenie” na dotychczas istniejących jednostkach. W niektórych przypadkach wprowadzano zmiany, aby możliwe było przyporządkowanie kosztów do ich rzeczywistych twórców, np. połączono dwa wydziały w jedno centrum odpowiedzialności. Kierunek zaobserwowanych zmian, a mianowicie zmniejszenie natężenia wytypowanych cech strukturalnych, wskazuje na zwiększenie stopnia organiczności struktur organizacyjnych badanych przedsiębiorstw, zgodnie z koncepcja T. Burnsa i G.M. Stalkera.

Odwrotny kierunek zmian zidentyfikowano natomiast w przypadku wymiaru formalizacji. Wdrożeniu controllingu towarzyszył bowiem wzrost jej natężenia, wynikajacy ze zwiększenia liczby dokumentów organizacyjnych i operacyjnych obowiązujących w przedsiębiorstwie oraz zwiekszenia zawartości i szczegółowości dokumentów dotychczas istniejących. W pierwszej odsłonie może to być interpretowane jako przejaw zmniejszenia stopnia organiczności struktury organizacyjnej, jednak bardziej wnikliwa analiza tego zjawiska wskazuje, że nie wywoływało to spowolnienia i ograniczenia elastyczności w działalności firmy. Wprowadzane dokumenty regulowały bowiem głównie działalność planistyczno-kontrolną i analityczną. W wielu przypadkach efekt był wręcz odwrotny. Dzięki stosowaniu instrumentów controllingowych i przy wykorzystaniu technologii informatycznej w zakresie gromadzenia i przetwarzania danych, nastąpiło zwiększenie możliwości szybkiego reagowania na bodźce, zarówno wewnętrzne, jak i zewnętrzne. Posiadanie większej ilości, bardziej szczegółowych i wieloprzekrojowych informacji o kosztach, przychodach i rentowności poszczególnych produktów czy jednostek organizacyjnych oraz możliwość dokonywania symulacji działalności firmy, umożliwiły bardziej płynne i elastyczne realizowanie zadań w przedsiębiorstwie. Wykorzystanie sprzętu komputerowego i odpowiedniego oprogramowania powoduje, że formalizacja związana z wdrożeniem controllingu jest zjawiskiem innym jakościowo, aniżeli formalizacja w ujęciu klasyków, np. M. Webera. Nie wywołuje bowiem przerostu biurokracji, spowolnienia i pogorszenia ja- kości podejmowanych decyzji, a wręcz przeciwnie, powoduje zwiększenie szybkości i poprawę elastyczności funkcjonowania organizacji. Wobec postępujących w ostatnich latach zmian technologicznych, umożliwiających wprowadzanie takich rozwiąań, jak zintegrowane systemy informatyczne, przechowywanie dokumentacji organizacyjnej w formie elektronicznej i bieżąca jej aktualizacja czy komunikacja poprzez internet, należałoby zredefiniować pojęcie formalizacji i jej relacje z pojęciem organiczności. Wydaje się bowiem, że obecnie wysoki stopień formalizacji przy wykorzystaniu odpowiednich narzędzi nie wyklucza wysokiego stopnia organiczności struktury organizacyjnej, tak jak to miało miejsce w połowie ubiegłego wieku, gdy formalizacja wiązała się ze znaczną pracochłonnością i oznaczała znaczne usztywnienie działalności przedsiębiorstw.

Generalnie, kierunek zmian intensywności cech strukturalnych świadczy o przeobrażaniu się struktury organizacyjnej w kierunku rozwiązań dywizjonalnych, o wyższym stopniu organiczności, niż tradycyjne struktury funkcjonalne $\mathrm{z}$ rozbudowaną hierarchią i uprawnieniami skupionymi na najwyższych szczeblach.

Jakościowa analiza badanych zjawisk uzupełniona została w wybranych przedsiębiorstwach pomiarem natężenia wytypowanych cech strukturalnych przed i po wdrożeniu controllingu. Na podstawie prezentowanych w literaturze koncepcji pomiaru cech strukturalnych opracowane zostały wskaźniki umożliwiające pomiar natężenia konfiguracji, specjalizacji, centralizacji i formalizacji ${ }^{4}$. Wskaźniki opracowane zostały w taki sposób, że ich wartości w każdym przypadku mieszczą się w przedziale od 0 do 1 . Im większe natężenie cech strukturalnych, tym wyższe wartości wskaźników i tym niższy stopień organiczności struktury organizacyjnej (tym bardziej jest ona mechanistyczna).

Wyniki pomiarów cech strukturalnych dokonanych w wybranych przedsiębiorstwach przed i po wdrożeniu controllingu przedstawia tabela. Do badań dobrano takie przedsiębiorstwa, które prezentuja możliwie najszersze spektrum zmian strukturalnych, tj. występowały w nich najbardziej zróżnicowane zmiany pod względem organizacji centrów odpowiedzialności i komórek ds. controllingu.

Wartości wskaźników potwierdzają wyniki analizy jakościowej, tj. ogólne zmniejszenie natężenia wytypowanych cech, a zatem wzrost organiczności struktury organizacyjnej. Autor ma świadomość słabości dokonanego pomiaru, wynikających między innymi z braków informacji historycznej i konieczności bazowania na pamięci respondentów, z różnej szczegółowości analizowanych dokumentów, jak również niedoskonałości związanych z uproszczeniami zastosowanymi przy opracowywaniu wykorzystanych wskaźników. Pomiar ten stanowi jednak uzupełnienie i potwierdzenie przeprowadzonych obserwacji i relacji przedstawicieli firm, przekazywanych w trakcie wywiadów. Istotne są tu nie tyle konkretne wartości wskaźników, lecz obserwowane dynamicznie zmiany. Proponowane połączenie jakościowej analizy zjawisk i aparatu ilościowego pozwala na obiektywizację uzyskanego obrazu badanej rzeczywistości. 
Tab. Wartości wskaźników natężenia cech strukturalnych w badanych przedsiębiorstwach przed i po wdrożeniu controllingu

\begin{tabular}{|l|l|l|l|c|}
\hline \multirow{2}{*}{ Nazwa firmy } & \multicolumn{4}{|c|}{ Wartości wskaźników } \\
\cline { 2 - 5 } & \multicolumn{3}{|c|}{ Przed wdrożeniem controllingu } & \multicolumn{2}{c|}{ Po wdrożeniu controllingu } \\
\hline \multirow{2}{*}{ Firma A } & K: 0,38 & S: $0,92 / 0,79^{5}$ & K: 0,35 & S: $0,75 / 0,83$ \\
\cline { 2 - 5 } & C: 0,64 & F: 0,70 & C: 0,56 & F: 0,77 \\
\hline \multirow{2}{*}{ Firma B } & K: 0,52 & S: $0,75 / 0,77$ & K: 0,52 & S: $0,75 / 077$ \\
\cline { 2 - 5 } & C: 0,69 & F: 0,72 & C: 0,64 & F: 0,75 \\
\hline \multirow{2}{*}{ Firma C } & K: 0,68 & S: $0,75 / 0,63$ & K: 0,66 & S: $0,75 / 0,63$ \\
\cline { 2 - 5 } & C: 0,58 & F: 0,67 & C: 0,52 & F: 0,72 \\
\hline \multirow{2}{*}{ Firma D } & K: 0,42 & S: $0,91 / 0,66$ & K: 0,40 & S: $0,91 / 0,63$ \\
\cline { 2 - 5 } & C: 0,59 & F: 0,60 & C: 0,59 & F: 0,63 \\
\hline \multirow{2}{*}{ Firma E } & K: - & S: $0,58 / 0,61$ & K: - & S: $0,66 / 0,65$ \\
\cline { 2 - 5 } & C: 0,74 & F: 0,47 & C: 0,65 & F: 0,47 \\
\hline
\end{tabular}

Źródło: opracowanie własne.

\section{Podsumowanie}

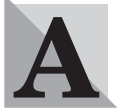
naliza literatury przedmiotu i przeprowadzone badania empiryczne wskazują na istnienie związków pomiędzy wdrożeniem i stosowaniem controllingu w przedsiębiorstwie a kształtem jego struktury organizacyjnej. Główne obszary zmian w tym zakresie to wyodrębnianie centrów odpowiedzialności i tworzenie komórek ds. controllingu. W literaturze przedmiotu zaprezentowano wiele bardzo różnorodnych propozycji konkretnych rozwiązań w tych obszarach. Ich efektywność wydaje się być w dużym stopniu uwarunkowana sytuacyjnie. Zmiany zidentyfikowane w praktyce dolnośląskich przedsiębiorstw, mimo mniejszego zakresu w stosunku do postulatów teoretycznych, również charakteryzują się znacznym stopniem różnorodności. Wyodrębniane centra odpowiedzialności miały bowiem różny poziom autonomii, wydzielone były według odmiennych kryteriów, obejmowały całe przedsiębiorstwa lub jedynie wybrane obszary. W kwestii organizacji komórek controllingowych również spotykano bardzo różnorodne rozwiąania. Mimo szerokiego spektrum omawianych zmian, kierunek przeobrażenia struktury organizacyjnej pod wpływem controllingu wydaje się być zbieżny. Wdrożenie $\mathrm{i}$ stosowanie controllingu $\mathrm{w}$ badanych przedsiębiorstwach implikowało zmiany, które skutkowały zmniejszeniem natężenia wytypowanych cech strukturalnych, w wyniku czego wzrastał stopień organiczności struktury organizacyjnej. Znalazło to odzwierciedlenie zarówno w jakościowej analizie zjawisk w badanych przedsiębiorstwach, jak również w wynikach pomiaru natężenia cech strukturalnych, dokonanego przed i po wdrożeniu controllingu, w pięciu wybranych jednostkach.

Zaprezentowane rozważania wskazują dość znaczącą rolę controllingu jako jednego z współczesnych czynników strukturotwórczych. Rodzi się na tym tle pytanie o oddziaływanie na strukturę organizacyjną innych współczesnych czy też nowoczesnych koncepcji i metod zarządzania, takich jak zarządzanie przez jakość (TQM), zarządzanie zasobami ludzkimi (HRM), zarządzanie procesami i projektami, organizacja wirtualna, organizacja ucząca się czy zarzą- dzanie wiedza. Może to być interesujacy problem badawczy.

dr Janusz Marek Lichtarski Katedra Teorii Organizacji i Zarzadzania Akademia Ekonomiczna we Wrocławiu

PRZYPISY

1) Zob. m.in.: L. MARTAN, J. WILIMOWSKI, Kilka uwag o controllingu i kontroli wewnetrznej, „Przeglad Organizacij”, $\mathrm{nr}$ 7-8 97, s. 54; H. STEINMANN, A.G. SCHERER, Strategiczny $i$ operatywny controlling (propozycja metodycznego określenia pojęć). Organizacja i Kierowanie", nr 1/96, s. 5-6.

2) L. KRZYZANOWSKI, Podstawy nauk o organizacji i zarzadzaniu, Wydawnictwo Naukowe PWN, Warszawa 1994, s. 196.

3) Wytypowano cztery klasy wielkości przedsiębiorstw (mierzonej stanem zatrudnienia): mikroprzedsiebiorstwa: 0-9 zatrudnionych, małe firmy: 10-50 zatrudnionych, średnie: 51-250 i duże: powyżej 250 zatrudnionych.

4) Wykorzystano tu przede wszystkim koncepcje tzw. Szkoły Astońskiej (D.S. Pugh, D. Hickson, B. Hinings, G. Harding i inni), a także podejścia A. Kiesera i H. Kubicka, S.P. Robbinsa oraz M. Przybyły.

5) Zakres/stopień.

BIBLIOGRAFIA

[1] BIENIOK H., ROKITA J., Struktura organizacyjna przedsiębiorstwa, Państwowe Wydawnictwo Naukowe, Warszawa 1984.

[2] GOLISZEWSKI J., Controlling - system koordynacji przedsiebiorstwa (I), „Przeglad Organizacji”, nr 8-9/90.

[3] KIESER A., KUBICEK H., Organisation, Walter de Gruyter, Berlin 1992.

[4] KRZYZANOWSKI L., Podstawy nauk o organizacji i zarzadzaniu, Wydawnictwo Naukowe PWN, Warszawa 1994.

[5] MARTAN L., WILIMOWSKI J., Kilka uwag o controllingu $i$ kontroli wewnetrznej, ,Przeglad Organizacji”, nr 7-8/97.

[6] PUGH D.S., HICKSON D.J., Organizational Structure in Its Context. The Aston Programme I, Saxon House, Westmead 1976.

[7] PUGH D.S., HININGS C. R. (red.), Organizational Structure: Extensions and Replications, The Aston Programme II, Saxon House, Westmead 1976.

[8] ROBBINS S.P., Organization Theory. Structure, Design and Applications, Prentice Hall, Englewood Cliffs, New Jersey 1990.

[9] PRZYBYŁA M., Struktura organizacji. Ujęcie wielowymiarowe, Forum, Wrocław 1995.

[10] MREŁA K., Struktury organizacyjne. Analiza wielowymiarowa, Państwowe Wydawnictwo Ekonomiczne, Warszawa 1983.

[11] NALEPKA A., Struktura organizacyjna, Antykwa, Kraków 2001.

[12] NOWOSIELSKI S., Centra kosztów i centra zysku w przedsiebiorstwie, Wydawnictwo Akademii Ekonomicznej we Wrocławiu, Wrocław 2001.

[13] STEINMANN H., SCHERER A.G., Strategiczny i operatywny controlling (propozycja metodycznego określenia pojęć), „Organizacja i Kierowanie", nr 1/96.

[14] VOLLMUTH H. J., Controlling. Planowanie, kontrola, kierowanie, Agencja Wydawnicza Placet, Warszawa 1998.

[15] WEBER J., Wprowadzenie do controllingu, Oficyna Controllingu Profit, Katowice 2001. 